\title{
Natural occurrence of Cucumber mosaic virus infecting water mint (Mentha aquatica) in Antalya and Konya, Turkey
}

\author{
Mehmet A. SEVIK \\ Department of Plant Protection, Faculty of Agriculture, University of Ondokuz Mayis, \\ Samsun, Turkey
}

\begin{abstract}
A virus causing a disease in mint (the aromatic and culinary plant) has recently become a problem in the Taurus Mountains, a mountain range in the Mediterranean region of Turkey. To detect the virus and investigate its distribution in the region, mint leaf samples were collected from the vicinity of spring areas in the plateaus of Antalya and Konya in 2009. It was found that Cucumber mosaic virus (CMV) was detected in $27.08 \%$ of symptomatic samples tested by DAS-ELISA. To the best of our knowledge, this is the first report of CMV on mint plants in this region of Turkey.
\end{abstract}

Key words: Disease, Cucumber mosaic virus, detection, Mentha aquatica

\section{Introduction}

Mentha is a genus of flowering plants in the family Lamiaceae including about 30 species found in the temperate regions of the world (DORMAN et al. 2003). Species such as $M$. aquatica L. and M. longifolia (L.) are used as wild vegetables and culinary herbs (NAGHIBI et al. 2005). M. aquatica (water mint) is a perennial plant. As the name suggests, it occurs in the shallow margins and channels of streams, rivers, pools, dikes, ditches, canals, wet meadows, marshes and fens (LING 2011).

Several viruses have been associated with disease symptoms in mint including Cucumber mosaic virus, Alfalfa mosaic virus, Tomato spotted wilt virus, Impatiens necrotic spot virus, Arabis mosaic virus, Strawberry latent ringspot virus, Tobacco mosaic virus, Tobacco ringspot virus, Tomato leaf curl virus, Tomato aspermy virus, Cherry rasp leaf virus, Lychnis ringspot virus, Mint virus 1, Mint virus-2, Mint virus X, Mint vein banding associated virus, Peppermint latent virus, and Peppermint stunt virus (VICCHI and BELLARDI 1988, Sether et al. 1991, De Angelis et al. 1993, Fletcher 2001, Postman et al. 2004, TZANETAKIs et al. 2004, SAMAD et al. 2008, TZANETAKIS et al. 2010).

\footnotetext{
* Corresponding author, e-mail: malis@omu.edu.tr

Copyright ${ }^{\circledR} 2012$ by Acta Botanica Croatica, the Faculty of Science, University of Zagreb. All rights reserved.
} 
Cucumber mosaic virus (CMV), the type member of the plant virus genus Cucumovirus (family Bromoviridae), has a wide host range and infects a great variety of important crop plants, making it one of the most economically significant plant viruses (PALUKAITIS et al. 1992). CMV infects more than 1200 plant species (RoOssINCK et al. 2001). Its ubiquitous nature may be attributed to its broad host range, non-persistent transmission by more than 86 aphid species in the field (EDWARDSON and CHRISTIE 1991) and transmission through seed in some hosts (O' KEEFE et al. 2007). Seed transmission plays a pivotal role in the survival of the virus from season to season (JOHANSEN et al. 1994). Therefore, the management of a CMV outbreak is difficult in the field (GRUBE et al. 2000). Ornamental plants, especially those propagated vegetatively as bulbs or rhizomes may be virus reservoirs (FLASINSKI et al. 1995). Interestingly, water mint is a herbaceous rhizomatous perennial plamt. The rhizomes are wide-spreading, fleshy, and bear fibrous roots. Moreover, an important number of plant species, including many weeds, have been reported to serve as reservoirs for CMV during the intercropping season (CHATZIVASSILIOU et al. 2004).

In previous studies, CMV infections have been frequently reported from Turkey on different plant families showing mild to severe symptoms (ERDILLER and ERTUNÇ 1988, YILMAZ et al. 1995, ARLI-SOKMEN et al. 2005). In recent years, in mint-growing areas around water springs of Antalya and Konya plateaus, a virus-like disease has become a major problem causing severe symptoms. The virus-like symptoms are exhibited by many mint plants, but little is known about the etiology of the disease. The objectives of the study were to identify the virus and characterize the disease it caused.

\section{Materials and methods}

\section{Surveys and sample collection}

In 2009, surveys were performed in 14 natural spring water areas in some plateaus of Antalya and Konya provinces containing mint plants. Leaf samples showing virus-like symptoms were taken from mint plants exhibiting symptoms, placed in polythene bags and stored at $-20{ }^{\circ} \mathrm{C}$ until use.

\section{Serological testing}

DAS-ELISA method was used to detect the virus in mint leaf samples and performed according to CLARK and ADAMS (1977) and the instructions of the CMV antiserum manufacturer (Bioreba, Switzerland). Leaf samples with typical symptoms of virus infections were ground ( $1 \mathrm{~g}$ leaf $/ 5 \mathrm{~mL}$ buffer) in extraction buffer (PBS: $0.13 \mathrm{M} \mathrm{NaCl}, 0.014 \mathrm{M}$ $\mathrm{KH}_{2} \mathrm{PO}_{4}, 0.08 \mathrm{M} \mathrm{Na}_{2} \mathrm{HPO}_{4}, 0.002 \mathrm{M} \mathrm{KCl}, \mathrm{pH}: 7.4$, containing $0.05 \%$ Tween-20), added to microplate wells (Nunc Microwell, Denmark) after coating with CMV-specific polyclonal antiserum diluted in carbonate buffer ( $\mathrm{pH}$ : 9.6) and incubated at $4{ }^{\circ} \mathrm{C}$ overnight. Plates were washed three times with PBS/Tween-20 buffer and coated with alkaline phosphatase-conjugated antibody diluted in extraction buffer and incubated for $4 \mathrm{~h}$ at $37^{\circ} \mathrm{C}$. After washing, p-nitrophenyl phosphate (Sigma) in diethanolamine substrate buffer $\left(0.5 \mathrm{mg} \mathrm{mL}^{-1}, \mathrm{pH}\right.$ : 9.8) was added to the wells and incubated at room temperature for 30-180 min. Absorbance values were read at $405 \mathrm{~nm}$ using a microplate reader (Tecan Spectra II). Extraction buffer and healthy plants were used as negative controls. Samples were considered to be 
positive when the absorbance values at $405 \mathrm{~nm}\left(\mathrm{~A}_{405}\right)$ values exceeded the mean of the negative controls by least a factor of three (KUTLUK-YILMAZ 2010).

\section{Biological testing}

Nicotiana tabacum L. 'Samsun' was grown in a growth chamber at $23{ }^{\circ} \mathrm{C}$ with a $16 \mathrm{~h}$ light/8 h dark photoperiod cycle. The samples of water mints collected (previously used for ELISA) were used for preparation of inoculum in the buffer and all fully expanded leaves of plants at 2-4 leaves growth stage were inoculated.

\section{Results and discussion}

Most of the farmers and people of Antalya and Konya regions complained of an increased incidence of mosaic disease in mint plants over the past few years. Besides their culinary use, mint plants are also used during livestock grazing. It is well known that mint has been used for centuries for its medicinal properties and in the food and fragrance industries (MimicA-Dukic et al. 2003).

Visual surveys of the mint plants revealed a high incidence of leaf mosaic (Fig. 1), deformation and severely affected apical plant growth. The newly growing apical leaves were small with very conspicuous symptoms. During the surveys, most spring areas contained plants with virus-like symptoms. Virus-like symptoms were observed in all 14 mints grown areas surveyed.

CMV was detected by DAS-ELISA in the mint plants from all surveyed areas. The incidence of CMV in the symptomatic plants varied in the different springs. Serological assay results revealed a variation in virus incidence among the different springs surveyed. The incidence of CMV was estimated as $27.08 \%$ in Antalya and Konya provinces, ranging from $14.2 \%$ to $42.8 \%$ in the springs visited.

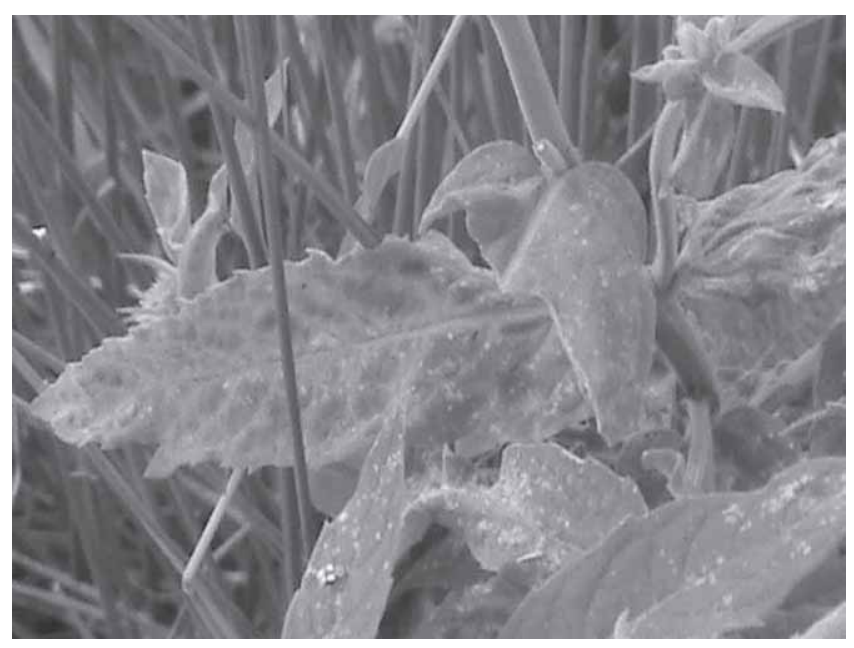

Fig. 1. Symptoms associated with natural infections by CMV on water mint plants. 
Tab. 1. Range of absorbance values of positive and negative samples and incidence of CMV.

\begin{tabular}{ccccc}
\hline \multirow{2}{*}{$\begin{array}{c}\text { No. of springs } \\
\text { surveyed }\end{array}$} & \multirow{2}{*}{$\begin{array}{c}\text { No. of } \\
\text { samples tested }\end{array}$} & \multicolumn{2}{c}{ The means DAS-ELISA absorbance values } & Incidence (\%) \\
\cline { 3 - 4 } & 12 & $0.084-0.215$ & $0.767-1.231$ & 16.6 \\
2 & 4 & $0.090-0.193$ & 0.829 & 25.0 \\
3 & 8 & $0.059-0.330$ & $\mathbf{0 . 4 5 2 - 0 . 6 6 9}$ & 37.5 \\
4 & 10 & $0.104-0.364$ & $0.860-1.076$ & 20.0 \\
5 & 6 & $0.093-0.316$ & $1.290-\mathbf{1 . 8 4 2}$ & 33.3 \\
6 & 5 & $0.110-0.299$ & 1.082 & 20.0 \\
7 & 7 & $0.075-0.317$ & $0.773-0.803$ & 42.8 \\
8 & 7 & $0.060-0.262$ & 1.318 & 14.2 \\
9 & 9 & $0.124-0.355$ & $0.793-0.916$ & 22.2 \\
10 & 8 & $0.078-0.326$ & $0.510-0.599$ & 37.5 \\
11 & 7 & $0.066-0.303$ & $0.685-0.697$ & 28.5 \\
12 & 6 & $0.088-0.249$ & 0.860 & 16.6 \\
13 & 3 & $0.115-0.354$ & 0.965 & 33.3 \\
14 & 4 & $0.128-0.338$ & $0.495-0.852$ & 28.5 \\
\hline
\end{tabular}

In the study, tests were conducted using several negative controls for CMV. Therefore, the range of absorbance values of negative controls varied from $0.066-0.118$ at $405 \mathrm{~nm}$. Positive samples gave absorbance values of $0.452-$ to 1.842 after $2 \mathrm{~h}$ substrate incubation (Table 1).

The presence of CMV in water mint plant was verified in samples by transmission to indicator test plants, tobacco (N. tabacum). Tobacco plants mechanically inoculated with extracts of ELISA-positive plants showed local necrotic spot on leaves 1 week after inoculation (Fig. 2). These symptoms were similar to those that were described previously for the virus (CHOI et al. 2004).

The cucumovirus CMV has been reported as the virus infecting different plants worldwide (VARVERI, and BoutsiKa 1999) and different regions of Turkey (ERDILlER and ERTUNÇ 1988, UNLU and GULDUR 2004), but infection of mint with CMV is reported for the first time in these regions. The report of CMV affecting Mentha was in 1966 in Germany, where it was found to be the cause of a mosaic disease of peppermint. CMV was found in cultivated medicinal plants, including mint, in Hungary (TZANETAKIS et al. 2010). HANI (1971) studied the epidemiology of CMV in Switzerland and reported Mentha sp. as a weed host for the virus in the vicinity of tobacco fields where several CMV isolates were causing problems. CMV was also isolated from Mentha sp. (VICCHI and BELLARDI 1988), M. piperita and M. palustris in Italy by CRESCENZI et al. (1993). M. pulegium for CMV was found infected for the first time by ElisA in Greece (CHATZIVASSILIOU et al. 2004).

Weeds, native plants and seed transmission may have a significant effect on virus epidemiology (DufFus 1971) and knowledge of weed reservoirs and vectors of viruses is essential for understanding the epidemiology. CMV-infected weeds may also play a significant role in its spread to crops. In 1998, 28 fields in Samsun, Turkey were surveyed and 222 


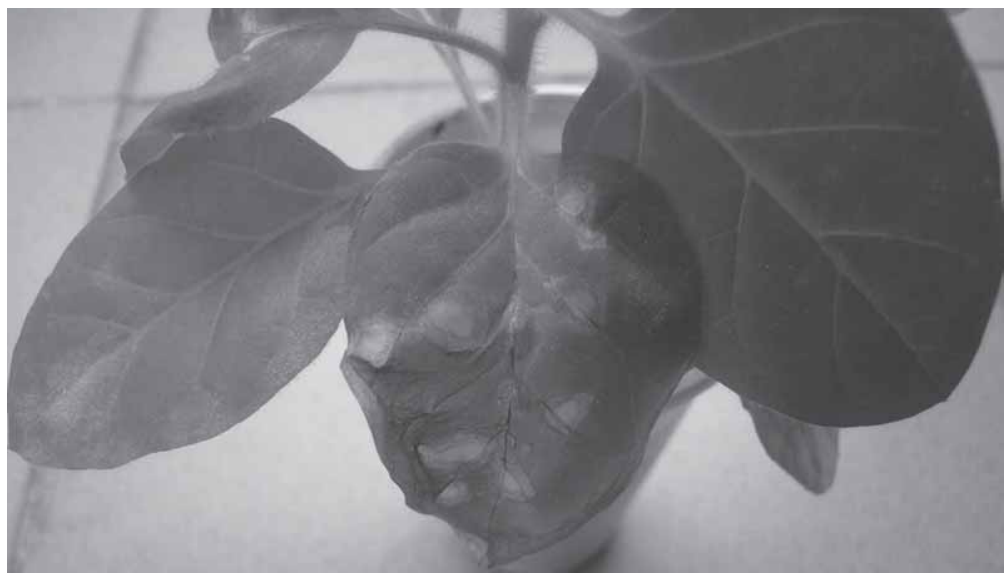

Fig. 2. Virusinoculated tobacco (Nicotiana tabacum L. 'Samsun') showing local necrotic spots on leaves, characteristic of CMV infection.

weed samples were collected from pepper fields. Of the samples tested, 7.7\% were found to be infected with CMV. CMV was found to be the virus most frequently detected, in 13 weed species out of 24 species (ARLI-SOKMEN et al. 2005). In experimental work, the virus is most frequently transmitted mechanically, and sap, purified virions, and viral RNA are all infectious via mechanical transmission (RoossincK 2001). In addition, DHEEPA and PARANJOTHI (2010) reported that CMV from banana could be transmitted by rhizome inoculation and mechanical methods. To help prevent CMV from spreading, farmers are recommended to remove any mint plants infected with CMV near springs.

The results obtained in this investigation clearly demonstrate that CMV is widely distributed in different mint growing areas of Antalya and Konya, Turkey. This is the first report of CMV from water mint plants (M. aquatica) in Turkey.

\section{Acknowledgments}

I thank to D. Sevik for helping and assistance during surveys of these regions and sample collections.

\section{References}

Arli-Sokmen, M., Mennan H, Sevik M. A., Ecevit O., 2005: Occurrence of viruses in field-grown pepper crops and some of their reservoir weed hosts in Samsun, Turkey. Phytoparasitica 33, 347-358.

Chatzivassiliou, E. K., Efthimiou, K., Drossos, E., Papadopoulou, A., Poimenidis, G., KATIS, N. I., 2004: A survey of tobacco viruses in tobacco crops and native flora in Greece. European Journal of Plant Pathology 110, 1011-1023.

ChoI, G. S., KIM, J. H., KIM, J. S., CHOI, J. K., 2004: Characterization of Cucumber mosaic virus isolated from water chickweed (Stellaria aquatica). Plant Pathology Journal 20, 131-134. 
Clark, M. R., Adams, A. M., 1977: Characteristics of the microplate method of enzyme linked immunosorbent assay for the detection of plant viruses. Journal of General Virology 34, 475-483.

Crescenzi, A., Barbarossa, L., Gallitelli, D., Martelli, G. P., 1993: Cucumber mosaic cucumovirus populations in Italy under natural epidemic conditions and after a satellite-mediated protection test. Plant Disease 77, 28-33.

De Angelis, J. D., Sether, D. M., Rossignol, P. A., 1993: Survival, development, and reproduction in western flower thrips (Thysanoptera, Thripidae) exposed to Impatiens necrotic spot virus. Environmental Entomology 22, 1308-1312.

DheEPA, R., PARANJothi, S., 2010: Transmission of Cucumber mosaic virus (CMV) infecting banana by aphid and mechanical methods. Emirates Journal of Food and Agriculture 22, 117-129.

Dorman, H. J, Kosar, M., Kahlos, K., Holm, Y., Hiltunen, R., 2003: Antioxidant properties and composition of aqueous extracts from mentha species, hybrids, varieties, and cultivars. Journal of Agricultural and Food Chemistry 51, 4563-4569.

Duffus, J. E., 1971: Role of weeds in the incidence of virus diseases. Annual Review of Phytopathology 9, 319-340.

Edwardson, J. R., Christie, R. G., 1991: Cucumoviruses. In: CRC Handbook of viruses infecting legumes, 293-319. CRC Press, Boca Raton.

ERDILlER, G., ERTUNÇ, F., 1988: Identification of muskmelon viruses in Ankara province. Journal of Turkish Phytopathology 17, 47-56.

Flasinski, S., Scott, S. W., Barnett, O. W., Sun, C., 1995: Diseases of Peperomia, Impatiens and Hibbertia caused by Cucumber mosaic virus. Plant Disease 79, 843-848.

Fletcher, J. D. 2001: New hosts of Alfalfa mosaic virus, Cucumber mosaic virus, Potato virus Y, Soybean dwarf virus, and Tomato spotted wilt virus in New Zealand. New Zealand Journal of Crop and Horticultural Science 29, 213-217.

Grube, R. C., Zhang, Y., Murphy, J. F., Loaiza-Figueroa, F., Lackney, V. K., Provvidenti, R., JAHN, M. K., 2000: New source of resistance to Cucumber mosaic virus in Capsicum frutescens. Plant Disease 84, 885-891.

Hani, A. 1971: On the epidemiology of Cucumber mosaic virus in Tessin. Phytopathologische Zeitschrift 72, 115-144.

Johansen, E., Edwards, M. C., HAMPTON, R. O., 1994: Seed transmission of viruses: current perspectives. Annual Review of Phytopathology 32, 363-386.

KuTLUK-YILMAZ, N.D. 2010: Interactions between beet necrotic yellow vein virus and beet soilborne virus in different sugar beet cultivars. Anadolu Journal of Agricultural Sciences $25,68-74$.

LING, C., 2011: Mentha aquatica. USGS Nonindigenous Aquatic Species Database, Gainesville, FL.

Mimica-Dukic, N., Bozin, B., Sokovic, M., Minajlovic, B., Matavulu, M., 2003: Antimicrobial and antioxidant activities of three Mentha species essential oils. Planta Medica 69, 413-419. 
Naghibi, F., Mosaddegh, M., Motamed, S. M., Ghorbani, A., 2005: Labiatae Family in folk Medicine in Iran: from Ethnobotany to Pharmacology. Iranian Journal of Pharmaceutical Research 2, 63-79.

O' Keefe, D. C., Berryman, D. I., Coutts, B. A., Jones, R. A. C., 2007: Lack of seed coat contamination with Cucumber mosaic virus in lupin permits reliable, large-scale detection of seed transmission in seed samples. Plant Disease 91, 504-508.

Palukaitis, P., Roossinck, M. J., Dietzgen, R. G., Francki, R. I. B., 1992: Cucumber mosaic virus. In: Maramorosch, K., Murphy, F. A. and Shatkin, A. J. (eds.), Advances in Virus Research, 281-348. Academic Press, San Diego.

Postman, J. D., Tzanetakis, I. E., Martin, R. R. 2004: First report of Strawberry latent ringspot virus in Mentha sp. from North America. Plant Disease 88, 907.

RoossincK, M. J., 2001: Cucumber mosaic virus, a model for RNA virus evolution. Molecular Plant Pathology 2, 59-63.

Samad, A., Gupta, M. K., Shasany, A. K., Ajayakumar, P. V., Alam, M., 2008: Begomovirus related to Tomato leaf curl Pakistan virus newly reported in Mentha crops in India. New Disease Reports 18, 11.

Sether, D. M., Deangelis, J. D., Rossignol, P. A. 1991: First report of Tomato spotted wilt virus in peppermint (Mentha piperita). Plant Disease 75, 644.

Tzanetakis, I. E., Postman, J. D., Martin, R. R., 2004: Identification, detection and phylogenetic analysis of new viruses infecting mint. Phytopathology 94, 104.

Tzanetakis, I. E., Postman, J. D., Samad, A., Martin, R. R., 2010: Mint viruses: Beauty, stealth, and disease. Plant Disease 94, 4-12.

UnLu, S., Guldur, M. E., 2004: Determination of infection ratio of Cucumber mosaic virus (CMV) on pepper in Sanliurfa. Journal of Faculty of Agriculture, Harran University $8,83-89$.

VARVERI, C., BOUTSIKA, K., 1999: Characterization of Cucumber mosaic cucumovirus isolates in Greece. Plant Pathology 48, 95-100.

VICCHI, V., BeLlardi, M. G., 1988: The role of weeds in the epidemiology of Gladiolus viruses and MLO. Acta Horticulture 234, 371-378.

Yilmaz, M. A., Baloglu, S., ÖZASlan, M., GÜldür, M. E., 1995: Plant viruses detected in horticultural crops in the GAP region (in Turish). Proc Symposium of Plant Protection Problems and Prevention, Suggestions of Gap Region, Sanliurfa, Turkey, 241-250. 